\title{
VYUŽITIE GLOBÁLNYCH SATELITNÝCH NAVIGAČNÝCH SYSTÉMOV PRE PRIBLÍŽENIA PODLA PRÍSTROJOV
}

\author{
Andrej Novák ${ }^{1}$, Ivan Ferencz ${ }^{2}$
}

\section{Úvod}

V súčasnosti je navigácia lietadiel vo fáze priblíženia zabezpečovaná tzv. konvenčnými navigačnými zariadeniami, ako sú ILS, VOR alebo NDB. Je samozrejmost'ou, že tieto navigačné zariadenia sa musia pravidelne obmieňat' a prípadne aj modifikovat', pretože okrem toho, že dochádza $\mathrm{k}$ ich fyzickému starnutiu sa $\mathrm{v}$ priebehu času menia aj názory na smerovanie toku letovej prevádzky na letisku.

Pre mnohé letiská predstavuje rozhodnutie obnovit’ navigačnú infraštruktúru letiska alebo niektorý jej prvok závažný, často neriešitel’ný problém. V dôsledku toho sa prevádzkujú letecké pozemné zariadenia, ktorých plánovaná životnost' už dávno uplynula a s ich obnovou sa váha. Rozhodovanie $\mathrm{v}$ záležitostiach obnovy navigačnej infraštruktúry neul'ahčuje ani skutočnost', že navigačná stratégia v európskom priestore je málo čitatel'ná, napríklad ciele uvedené v dokumente Navigation Strategy for ECAC z roku 1999 sa ukázali ako zjavne nerealistické, ved' napríklad letecké pozemné zariadenia VOR a NDB sa podl'a tohto strategického dokumentu v súčasnosti už nemali používat'.

Dnes sa ukazuje, že jedinou možnost'ou, ako najmä na menších letiskách udržat' prevádzku podl'a pravidiel na let podl'a prístrojov je využit' potenciál globálnych navigačných satelitných systémov.

\section{Možné druhy prevádzky}

Kým pri konvenčnej navigácii rozoznávame iba niekol'ko druhov prístrojového priblíženia, ktoré sú pomerne jednoznačne navzájom rozlíšitel'né, pri priestorovej navigácii je situácia podstatne zložitejšia. Popri zaužívanom rozdelení prístrojových priblížení na presné a nie-presné, bolo potrebné nájst' miesto pre druhy priblíženia, ktoré síce poskytujú vedenie aj vo vertikálnej rovine, ale nesplňujú požiadavky kladené na presné prístrojové priblíženia. Označujú sa pojmom „,priblíženie s vertikálnym vedením“ a principiálne je možné medzi nimi rozpoznat' dva druhy: priblíženia, pri ktorých je zostupová rovina definovaná pomocou

\footnotetext{
${ }^{1}$ doc. Ing. Andrej Novák, PhD., Žilinská univerzita v Žiline, Univerzitn 1, 01026 Žilina tel.: +421 41513 3456, fax: +421415131517

e-mail: Andrej.Novak@fpedas.uniza.sk

${ }^{2}$ Ing. Ivan Ferencz, Letecký úrad SR, Letisko M.R.Štefánika, 84101 Bratislava tel.: +42102, fax: +421415131517

e-mail: Ivan.Ferencz@caa.sk
} 
tlakového výškomera t.j. BARO-VNAV a také, kde je vertikálne vedenie zabezpečené využitím rozšírenia GNSS, napríklad SBAS. EASA AMC 20-27 umožňuje získat' schválenie

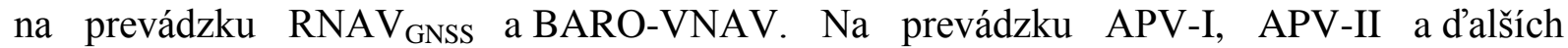
s prísnejšími charakteristikami budú príslušné certifikačné požiadavky vydané $\mathrm{V}$ nasledujúcich rokoch.[1,2]

\section{Priblíženie pomocou základného GNSS}

Priblíženie pomocou základného GNSS (Basic - GNSS) patrí do kategórie niepresných priblížení. Trat'ové vedenie je zabezpečené iba v horizontálnej rovine. Konštrukcie postupov prístrojového priblíženia založeného na GNSS boli možné už od roku 1998, kedy ICAO prvýkrát zverejnilo konštrukčné kritériá pre základný GNSS. Následne niektoré štáty ECAC zaviedli GPS postupy priblíženia, pričom na vytvorenie národného regulačného rámca, certifikáciu lietadiel a schválenie prevádzkovatel’ov použili návody uvedené v dokumente JAA TGL 3. JAA neskôr došlo $\mathrm{k}$ názoru, že požiadavky uvedené $\mathrm{v}$ JAA TGL 3 nie sú dostatočné a začalo práce na úplnej revízii tohto dokumentu, ktorý mal pracovný názov JAA TGL xx. Po prevzatí úloh JAA organizáciou EASA, sa dokument d’alej pripravoval ako EASA AMC 20-27. Podl'a pôvodného harmonogramu mal byt' tento publikovaný v roku 2006, príslušné rozhodnutie riaditel'a EASA bolo vydané v decembri 2009.

Tolerancie používané na konštrukciu jednotlivých segmentov letových postupov sú uvedené v tabul'ke.[3]

Tabul'ka :

Tolerancie na konštrukciu letových postupov pre základný GNSS

\begin{tabular}{|l|l|l|l|l|l|l|}
\hline & $\begin{array}{l}\text { Terminál } \\
\text { ny režim } \\
(\mathbf{k m} / \mathbf{N M})\end{array}$ & $\begin{array}{l}\text { IAF } \\
(\mathbf{k m} / \mathbf{N M})\end{array}$ & $\begin{array}{l}\mathbf{I F} \\
(\mathbf{k m} / \mathbf{N M})\end{array}$ & $\begin{array}{l}\text { FAF } \\
(\mathbf{k m} / \mathbf{N M})\end{array}$ & $\begin{array}{l}\text { MAPt } \\
(\mathbf{k m} / \mathbf{N M})\end{array}$ & $\begin{array}{l}\text { MAHF } \\
(\mathbf{k m} / \mathbf{N M})\end{array}$ \\
\hline $\begin{array}{l}\text { Navigačná } \\
\text { presnost' }\end{array}$ & $0.23 / 0.12$ & $0.23 / 0.12$ & $0.23 / 0.12$ & $0.23 / 0.12$ & $0.23 / 0.12$ & $0.23 / 0.12$ \\
\hline $\begin{array}{l}\text { Monitor } \\
\text { Integrity }\end{array}$ & $3.70 / 2.00$ & $1.85 / 1.00$ & $1.85 / 1.00$ & $0.56 / 0.30$ & $0.56 / 0.30$ & $1.85 / 1.00$ \\
\hline Čas do alarmu & $30 \mathrm{sec}$ & $10 \mathrm{sec}$ & $10 \mathrm{sec}$ & $10 \mathrm{sec}$ & $10 \mathrm{sec}$ & $10 \mathrm{sec}$ \\
\hline FTT & $3.70 / 2.00$ & $0.93 / 0.50$ & $0.93 / 0.50$ & $0.56 / 0.30$ & $0.37 / 0.20$ & $0.93 / 0.50$ \\
\hline ATT & $3.70 / 2.00$ & $1.85 / 1.00$ & $1.85 / 1.00$ & $0.56 / 0.30$ & $0.56 / 0.30$ & $1.85 / 1.00$ \\
\hline XTT & $7.41 / 4.00$ & $2.78 / 1.50$ & $2.78 / 1.50$ & $1.11 / 0.60$ & $0.93 / 0.50$ & $2.78 / 1.50$ \\
\hline $\begin{array}{l}\text { Ochranný } \\
\text { priestor }\end{array}$ & $14.82 / 8.00$ & $5.56 / 3.00$ & $5.56 / 3.00$ & $2.22 / 1.20$ & $1.85 / 1.00$ & $5.56 / 3.00$ \\
\hline
\end{tabular}

\section{Priblíženie s vertikálnym vedením Baro-VNAV}

Princíp Baro-VNAV spočíva vo vytvorení syntetickej zostupovej roviny kombináciou informácií o horizontálnej polohe lietadla voči RWY (LNAV) a výstupu z tlakového výškomera. Zostupová rovina je potom určená vertikálnym uhlom (VPA) a bodom v referenčnej výške nad prahom RWY $(\mathrm{RDH})$. Vo všeobecnosti, z hl'adiska techniky letu je takéto priblíženie podobné presnému prístrojovému priblíženiu v tom, že v postupe nie je 
identifikovaný fix konečného priblíženia (FAF) ani bod nevydareného priblíženia (MAPt) a nepoužíva sa minimálna zostupová výška (MDH), ale výška rozhodnutia(DH). Postup je chránený, podobne ako postup ILS, prekážkovými rovinami (OAS), avšak tieto sú odvodené $\mathrm{Z}$ výkonnosti systému horizontálnej navigácie. Kritériá na konštrukciu letových postupov Baro-VNAV zverejnilo ICAO v roku 2004. Certifikačné požiadavky sú uvedené v EASA AMC 20-27. [4]

Na vykonanie postupu Baro-VNAV je nevyhnutné splnenie týchto kritérií:

$>$ Palubný VNAV systém musí byt' schválený na vykonávanie priblížení a musí umožňovat' rýchly prechod na kurzové vedenie vo fáze nevydareného priblíženia

$>$ LNAV systém musí mat’ priečnu aj pozdížnu navigačnú výkonnost' lepšiu ako $0.3 \mathrm{NM}$, čo je možné splnit'

○ navigačným vybavením GNSS schváleným na priblíženia, alebo

○ viacsenzorovým systémom používajúcim blok inerčnej navigácie spolupracujúci s DME/DME alebo GNSS schváleným na priblíženia, alebo

○ RNP systém schválený na prevádzku RNP 0.3 alebo lepšiu

navigačná databáza musí obsahovat' trat'ové body a príslušné RNAV a VNAV údaje (RDH a VPA) o postupe vrátane údajov o postupe o nevydarenom priblížení, ktoré musia byt' automaticky nahrané do navigačného systému

\section{Priblíženie s vertikálnym vedením APV I/II}

Hlavný rozdiel medzi priblížením Baro-VNAV a APV I/II je v spôsobe, akým sa vytvorí zostupová rovina. V prípade priblíženia APV I/II sa tento účel predpokladá využitie družicového rozšírenia SBAS, v podmienkach SR to bude systém EGNOS. Certifikačné požiadavky budú zverejnené až vydaním EASA AMC 20-28.[6]

Požiadavky na horizontálnu presnost' sú rovnaké pre APV I a APV II rovnaké, $16.0 \mathrm{~m}$ (95\%), horizontálny výstražný limit (HAL) je 40.0m. Vertikálna presnost' pre APV I je $20.0 \mathrm{~m}$, kým pre APV II je to iba $8.0 \mathrm{~m}$. Vertikálny výstražný limit (VAL) pre APV I je $50.0 \mathrm{~m}$, pre APV II je VAL $20.0 \mathrm{~m}$. Na konštrukciu letových postupov sa používajú tolerancie uvedené v tabul'ke.

\begin{tabular}{|l|l|l|l|l|l|l|}
\hline & $\begin{array}{l}\text { Terminál } \\
\text { ny režim } \\
(\mathbf{k m} / \mathbf{N M})\end{array}$ & $\begin{array}{l}\text { IAF } \\
(\mathbf{k m} / \mathbf{N M})\end{array}$ & $\begin{array}{l}\mathbf{I F} \\
(\mathbf{k m} / \mathbf{N M})\end{array}$ & $\begin{array}{l}\text { FAF } \\
(\mathbf{k m} / \mathbf{N M})\end{array}$ & $\begin{array}{l}\text { MAPt } \\
(\mathbf{k m} / \mathbf{N M})\end{array}$ & $\begin{array}{l}\text { MAHF } \\
(\mathbf{k m} / \mathbf{N M})\end{array}$ \\
\hline $\begin{array}{l}\text { Navigačná } \\
\text { presnost' }\end{array}$ & $0.23 / 0.12$ & $0.23 / 0.12$ & $0.23 / 0.12$ & $0.23 / 0.12$ & $0.23 / 0.12$ & $0.23 / 0.12$ \\
\hline HAL & $1.85 / 1.00$ & $1.85 / 1.00$ & $1.85 / 1.00$ & $0.56 / 0.30$ & $0.56 / 0.30$ & $0.56 / 0.30$ \\
\hline FTT & $0.93 / 0.50$ & $0.93 / 0.50$ & $0.93 / 0.50$ & $0.56 / 0.30$ & $0.37 / 0.20$ & $0.37 / 0.20$ \\
\hline ATT & $1.85 / 1.00$ & $1.85 / 1.00$ & $1.85 / 1.00$ & $0.56 / 0.30$ & $0.56 / 0.30$ & $0.56 / 0.30$ \\
\hline XTT & $2.78 / 1.50$ & $2.78 / 1.50$ & $2.78 / 1.50$ & $1.11 / 0.60$ & $0.93 / 0.50$ & $0.93 / 0.50$ \\
\hline $\begin{array}{l}\text { Ochranný } \\
\text { priestor }\end{array}$ & $9.26 / 5.00$ & $5.56 / 3.00$ & $5.56 / 3.00$ & $2.22 / 1.20$ & $1.85 / 1.00$ & $1.85 / 1.00$ \\
\hline
\end{tabular}

Tolerancie na konštrukciu letových postupov založených na SBAS

Požiadavky na integritu, kontinuitu a dostupnost' signálu sú: integrita vyššia ako 1$1 \times 10^{-7}$, kontinuita lepšia ako $1-8 \times 10^{-6}$ počas l'ubovol'ných $15 \mathrm{~s}$ a dostupnost' v závislosti na 
viacerých faktoroch ako intenzita prevádzky, počasie, dostupnost' alternatívnych možností navigácie, radarové krytie a pod. má byt' lepšia ako $0.99-0.99999$.

Predpokladá sa, že technika pilotáže bude rovnaká ako pri priblížení ILS a tomu bude zodpovedat' aj tolerancia techniky pilotáže (FTT).

Postup je - podobne ako pri postupoch ILS - chránený prekážkovými rovinami OAS, ktoré sú pre APV I konzervatívnejšie ako pre APV II z dôvodu slabšej výkonnosti navigačného vybavenia. [7]

\section{Záver}

Leteckí prevádzkovatelia by sa mali snažit' získat' schválenie na prevádzku podl'a AMC 20-27 aj napriek tomu, že zatial' nejde o povinnost' Berúc do úvahy stratégiu ICAO, aby do konca roka 2014 bol na každej RWY k dispozícii postup prístrojového priblíženia s vertikálnym vedením, môžu očakávat' investícia do palubného vybavenia a splnenia certifikačných požiadaviek sa zúročí najmä v podobe lepšej dostupnosti letísk nevybavených systémom postup ILS aj pri horších meteorologických podmienkach. Druhou možnost’ou je počkat' na dokument EASA AMC 20-28 a získat' schválenie na prevádzku APV-I alebo APVII, ktorá umožní d’alšie zníženie prevádzkových miním.

Článok je publikovaný v súlade s projektom „Implementácia vedecko-výskumných poznatkov do leteckej dopravy“ ITMS 26220220010. Ktorého strategický ciel' je v súlade s hlavným ciel'om výzvy OPVaV-2008/2.2/01-SORO Operačného programu Výskum a vývoj Zvyšovanie miery spolupráce výskumno-vývojových inštitúcií so spoločenskou a hospodárskou praxou prostredníctvom prenosu poznatkov a technológií a tým prispievanie $\mathrm{k}$ zvyšovaniu hospodárskeho rastu regiónov a celého Slovenska. zdrojov EÚ

Podporujeme výskumné aktivity na Slovensku/ Projekt je spolufinancovaný zo
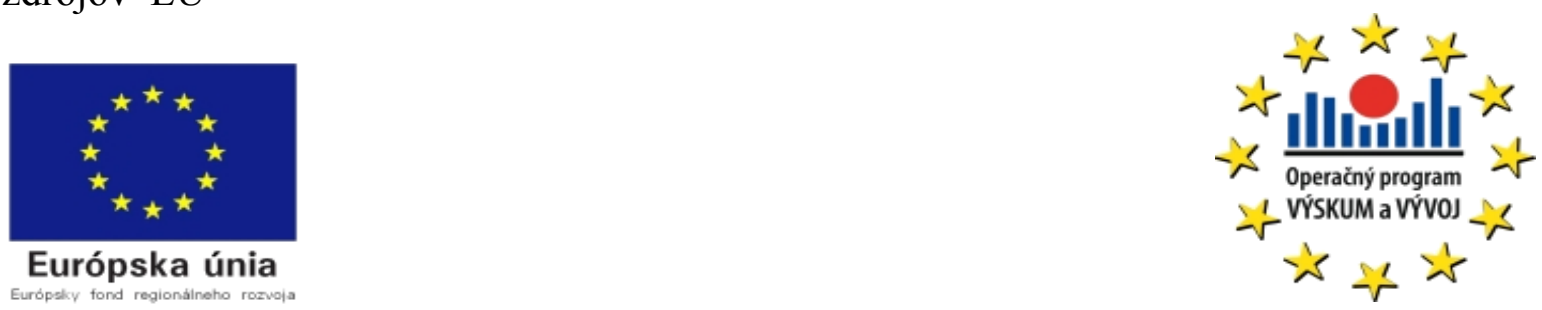

\section{Literatúra}

[1] Navigation Strategy for ECAC, Edition 2.1, EUROCONTROL, 1999

[2] ANNEX 10 to the Convention of International Civil Aviation, Aeronautical Telecommunications, Volume I, Radio Navigation Aids, 6th Edition, ICAO, Júl 2006

[3] AMC 20-27, Airworthiness Approval and Operational Criteria for RNP

[4] APPROACH (RNP APCH) Operations Including APV BARO VNAV Operations, EASA, 2009

[5] Leaflet NO 3, Rev 1: JAA Interim Guidance Material on Airworthiness Approval and Operational Criteria for the Use of the NAVSTAR Global Positioning System (GPS)

[6] Doc 8168 Ops/611, Procedures for Air Navigation Services, Aircraft Operations, Volume II, Construction of Visual and Instrument Flight Procedures, 5th Edition, ICAO, 2006

[7] Performance Based Navigation Manual (final working draft), ICAO, marec 2007 